\title{
Evaluating Watershed Hydrological Responses to Climate Changes at Hangar Watershed, Ethiopia.
}

\author{
Abdata Galata ${ }^{1}$, Kiyya Tullu ${ }^{1}$, and Abebe Guder ${ }^{1}$ \\ ${ }^{1}$ Jimma University Institute of Technology
}

August 20, 2020

\begin{abstract}
The aim of this study is to model the responses of Hangar watershed Hydrology to future climate changes under the two Representative concentration pathway (RCP) scenarios. Future changes in precipitation and temperature were produced using output of dynamically downscaled data of Regional Climate Model (RCM) $50 \mathrm{Km}$ resolution under RCP 4.5 and RCP 8.5 scenarios for 2025-2055 and 2056-2086. The future projection of the RCM model of climate parameters showed an increasing trend relative to the base period (1987-2017). At 2025-2055 an annual average precipitation increment of $+15.7 \%$ and $+19.8 \%$ expected for RCP 4.5 and RCP 8.5 respectively. For 2056-2086 of RCP 4.5 and RCP 8.5, also similar trend showed in which change in average annual precipitation may increase by $+20.1 \%$ and $+23.4 \%$ respectively. The changes of climate parameters used as input in to SWAT hydrological model to simulate the future runoff at the out let of gauging station. The increment in precipitation projection resulted in positive magnitude impact on average runoff flow. The average annual change in runoff at 2025-2055 of both RCP 4.5 and RCP 8.5 may by $+260.01 \mathrm{~m} 3 / \mathrm{s}$ and $+733.18 \mathrm{~m} 3 / \mathrm{s}$ respectively. At 2056-2086, change in average annual runoff of $+257.08 \mathrm{~m} 3 / \mathrm{s}$ and $+732.26 \mathrm{~m} 3 / \mathrm{s}$ for RCP 4.5 and RCP 8.5 may expected respectively. This increment may create an opportunity for community of the area to harness enough amount of water during most increased season for later use.
\end{abstract}

\section{INTRODUCTION}

The issues related to climate change are of prime concern for every nation around the Globe as its implications are posing negative impacts on society. It is now obvious that human being-related activities, including burning of fossil fuels, deforestation, and urbanization, have facilitated climate change. Climate change has direct impact on hydrological cycle which in turn starts a chain reaction impacting agriculture, energy and ecology, to name a few .Increasing concentrations of atmospheric greenhouse gases, and consequent global warming are almost certainly responsible for significant changes in global climatic patterns .

Evaluating the hydrological response to an increased climate change is critical for the proper management of water resources within agricultural systems. Consequently, such impacts of climate change have been widely studied, mainly using water balance models coupled with General Circulation Models (GCMs).Given the vital role of water resources in socio-economic development, the potential hydrological impacts of climate change pose a significant challenge for water resource planning and management. Shifts in the availability of water resources are expected to be among the most significant consequences of projected climate changes

Climate change is predicted to lead to an intensification of the global hydrological cycle.Climate impacts have been attributed to the associated long-term changes in the dominant climate variables: precipitation and temperature. Increased temperature is the most commonly identified issue regarding predicted changes in climate during the coming century, and the potential impacts of this warming have received the majority of attention (IPCC, 2007). Changes in precipitation patterns are anticipated to be a significant component 
of climate change as well. Climate change affects the function and operation of existing water infrastructures including hydropower, structural, drainage and irrigation systems as well as water management practices.

Climate change is likely to have severe effects on water availability in Ethiopia. Previous research has shown that the water resources of Ethiopia are highly sensitive to climate change and variability .The existing land and water resource system of the area is adversely affected by the rapid growth of population, deforestation, surface erosion, and sediment transport and climate change impacts. Climate change increases the vulnerability of poor people, affects their health and livelihoods and undermines growth opportunities crucial for poverty reduction .Extreme events due to anthropogenic climate change would cause forced migration and human resettlement resulting in the damage of the social cohesion including the loss of human lives and physical properties. Therefore, it is very important to quantify such impacts in order to identify the variation in decisions and thereby minimize the potential damage magnitude of climate change on a local and regional scale.

\section{METHODS AND MATERIALS}

\section{Study Area Description}

The study area located at the upper reaches of the Didessa River basin (Fig.1). The river is fed by tributaries flowing from the north-western slopes of Jardaga Jarte district. It drains to the south-west into Blue Nile River. The catchment area for this study is about $7673.87 \mathrm{~km}^{2}$, located between longitudes $36^{\circ} 31^{\prime}$ $41^{\prime \prime}$ and $37^{\circ} 06^{\prime} 50^{\prime \prime} \mathrm{E}$, and latitudes $9^{\circ} 41^{\prime} 58^{\prime \prime}$ and $9^{\circ} 59^{\prime} 56^{\prime \prime} \mathrm{N}$. The area has high topographic relief characterized by steeply sloping uplands and elevation ranging from 844 to 3207 ma.s.l. Most of the study area is covered with intrusive Precambrian rocks mainly granite with coarse-grained texture and massive in nature which is overlaid by thick black to brownish cotton soil. As per the data collected from the National Metrological Service Agency (NMSA), the study area receives heavy rainfall from June to September and experiences a limited amount of rainfall for the left seven months. Hangar watershed experienced the average maximum temperature experienced in the months of February, March, and April whereas, the average minimum temperature occurred in the months of September, October and November. In terms of land use, the area is characterized by intensive agricultural activities, forest and significant presence of shrub land.

\section{Data Availability and its analysis}

The necessary input data required for the SWAT model were Meteorological data, Stream flow data, Climate Scenario Data, DEM (Digital Elevation Model), Land use land cover and Soil data which were collated from different sources or institutions.

\section{Observed Meteorological and Stream flow data}

The meteorological data Such as daily precipitation, maximum and minimum temperature, sunshine hour data, relative humidity, and wind speed data were collected from the Ethiopian National Meteorology Service Agency. These data were used as the input to the SWAT hydrological model for the simulation of the hydrological components. Stream flow data were collected from Ministry of Water, Irrigation and Electricity (MoWIE).This data is required for calibration and validation of the SWAT model. To perform hydrological analysis and simulation using data of long time series, filling in missing data is very important. The missing data can be completed using meteorological and /or hydrological stations located in the nearby, provided that the stations are located in hydrological homogeneous region. In order to fill the missing observed rainfall and temperature data, joint application of the regression analysis and spatial interpolation techniques are used to complete short and long period breaks in data series for a given meteorological station. Such gaps in the record are filled by developing correlations between the station with missing data and any of the adjacent stations with the same hydrological features and common data periods. In this study missing of observed rain rainfall and Temperature values were estimated using XLSTAT by filling each from its neighboring stations.

\section{Climate Scenario Data}


A climate scenario is a representation of future climate conditions (temperature, precipitation and other climatological phenomena). CORDEX-Africa initiated by World Climate Research Program (WCRP) provides an opportunity for the generation of high resolution regional climate projections over Africa that is used to assess future impacts of climate change at regional and local scales. In this research, climate change scenarios data from the newly available CMIP5 Regional Climate Model(RCM) ensemble output of CORDEX-Africa for African domain projections under Representative Concentration Pathways (RCP4.5 and RCP8.5) were used as input to hydrological model. RCP scenarios have a better resolution that helps in performing regional and local comparative studies compared to previous climate scenarios, and RCP scenarios also represents an attractive potential approach for further research and assessment, including emissions mitigation and impact analysis.Therefore, in this Study, results of CORDEX-Africa ensemble RCM simulations for the historical and future climate projections under RCP4.5 mid-range and RCP8.5 high-level climate scenarios with spatial resolution of $0.44^{\circ}$ were used. The Data were obtained from (https://climate4impact.eu/impactportal/data/esgfsearch.jsp).

\section{Bias Correction}

In order to reduce uncertainty due to raw CORDEX data, bias correction was carried out for precipitation and temperature by the method of linear scaling (multiplicative) and linear scaling (additive) respectively. From this, the comparison of the generated projection data with respect to the observed analyzed climate data (base period data) resulted in producing a similar pattern for the Hangar watershed.

\section{DEM,}

\section{Land use/Land cover and Soil data}

Digital elevation model (DEM) of $12.5 \mathrm{~m}$ by $12.5 \mathrm{~m}$ resolution was downloaded from the website of Alaska satellite facility (https://www.asf.alaska.edu/sar-data/palsar/) for the delineation and topographic characterization of the watershed. It is also used to determine the hydrological parameters of the watershed such as slope, flow accumulation, direction and stream network. Land use/Land cover and Soil data were collected from Ministry of Water, Irrigation and Electricity. These data were used as the input to the SWAT hydrological model to define the Hydrological Responses Units.

\section{SWAT Model Description}

Soil and Water Assessment Tool (SWAT) is a basin- scale, continuous- time model that operates on a daily time step and is designed to predict the impact of management on water, sediment, and agricultural chemical yields in watersheds. The model is physically based, computationally efficient, and capable of continuous simulation over long time periods. Major model components include weather, hydrology, soil temperature and properties, plant growth, nutrients, pesticides, bacteria and pathogens, and land management. In SWAT, a watershed is divided into multiple sub watersheds, which are then further subdivided into hydrologic response units (HRUs) that consist of homogeneous land use, management, and soil characteristics. The HRUs represent percentages of the sub watershed area and are not identified spatially within a SWAT simulation.

SWAT was selected for the following reason:(a) SWAT is one of the promising and applicable rainfall-runoff models for developing countries which do not have enough data for fully distributed hydrological models. (b) It is also computationally efficient to operate on large basins in a reasonable time and capable of simulating long periods. (c)It is public domain software.

\section{Methodology}

The main tools that were used for input data preparation and analysis includes Arc SWAT, SWAT-CUP, PCPSTAT, Dew02.exe, XLSTAT, and Microsoft Excel. Figure 2 shows Schematic Diagram of the Study Frame Work.

\section{FINDINGS AND DISCUSSION}




\section{Base period climate projection (1987-2017)}

In addition to observed metrological data, the downscaled RCM climate data used to evaluate the hydrological responses to climate change. The comparison of average monthly projected minimum and maximum temperature and precipitation data with respect to observed data, showed uniformity pattern (Figure 1).This similarity indicated that the output of RCM simulated the reality of the observed temperature and precipitation in a better way with to a little extent over estimation and under estimation.

Future climate change projection for the first 30 years (2025-2055) and second 30 years (20562086)

Precipitation: The results of analysis showed an increasing trend of average monthly precipitation for both RCP 4.5 and RCP 8.5 scenarios except during the months of January, March and September as compared to the base line period. For 2025-2055, average projected seasonal precipitation change varied from $+9.8 \%$ to $+25.8 \%$ and $+12.1 \%$ to $+27.3 \%$ for RCP 4.5 and RCP 8.5 respectively. Maximum expected precipitation change projected in winter and spring than summer and autumn seasons. At 2056-2086 average seasonal precipitation change of $+15.7 \%$ to $+30.3 \%$ and +15.5 to $38.9 \%$ expected for RCP 4.5 and RCP 8.5 respectively (Figure 4). The results discussed in this study are within the range with other study which projected and presented over the Didessa catchment, the difference is they used RegCM3 GCM output and HBV model (Gebre et al., 2015).

\section{Temperature}

Minimum temperature: The trend of minimum temperature showed an increasing in both scenario projections where the maximum percentage change is expected in the months of February and December. Relatively the minimum percentage change of temperature is expected in November for both climate periods of RCP's. During November, average monthly minimum temperature change expectation varied from $+5.2 \%$ to $+5.8 \%$ and $+6.1 \%$ to $+6.9 \%$ at both climate projection horizons for RCP 4.5 and RCP 8.5 respectively. For RCP 4.5 at 2056-2086, maximum percentage change is $+9.9 \%$ and $+9.2 \%$ in February and December respectively. The maximum percentage change projected in February and December are $+9.6 \%$ and $+9.5 \%$ respectively for 2056-2086 of RCP 8.5 (Figure 5).

Maximum temperature: The projected percentage change of average monthly maximum temperature also showed increasing trend. At 2025-2055 and 2056-2086 of RCP 4.5 average monthly change in maximum temperature varied from $+2.1 \%$ to $+7.4 \%$ and $+2.7 \%$ to $9.7 \%$ respectively. For RCP 8.5 the change in average monthly maximum temperature ranges from $+2.6 \%$ to $+8.6 \%$ and from $+3.2 \%$ to $+9.8 \%$ at 2025 2055 and 2056-2086 respectively. The projected minimum and maximum temperature in both future time horizons of RCP's for the watershed is consistent with the projection presented by other researcher over the Blue Nile River basin (Setegn et al., 2011) (Figure 6).

\section{SWAT hydrological model calibration and validation results}

The SWAT model is calibrated and validated using twenty two years flow from 1990-2002 for calibration, and from 2003-2011for testing validation (Figure 7). The value of $\mathrm{R}^{2}$ and NSE obtained during calibration were 0.89 and 0.88 respectively. The sensitivity analysis showed that CN2, SURLAG and CANMX are the most three top sensitive parameters in the study area.

\section{Future impacts of climate change on runoff}

A change in climate parameters especially, temperature and precipitation have had significant impacts on the amount of runoff. Figure 8 showed the projected average monthly runoff increases varying from $+2.3 \%$ to $+75.6 \%$, and from $-0.4 \%$ to $+90.5 \%$ at $2025-2055$ and $2056-2086$ of RCP 4.5 respectively as compared to the base line period (1987-2017). At 2025-2055 and 2056-2086 of RCP 8.5 average monthly runoff also showed increasing trend ranging from $+0.4 \%$ to $+87.9 \%$ and $-22.1 \%$ to $+75.6 \%$ respectively. Generally, average seasonal runoff projection showed that runoff increases in most of the months, especially during summer seasons. Average annual runoff may expected to increase by $+24.5 \%$ and by $+73.2 \%$ at $2025-2055$ 
and 2056-2086 of RCP 4.5 respectively compared to base line period (1987-2017). Similarly, at 2025-2055 and 2056-2086 of RCP 8.5 runoff increment of $+23.6 \%$ and $+73.2 \%$ respectively are expected compared to base line period (Figure 9). The average seasonal and annual increment of runoff due to climate change at Hangar watershed is in line with other researcher projected presentation over Didessa catchment (Gebre et al., 2015).

\section{Conclusion}

This study assessed the effects of climate change on the hydrology of Hangar Watershed, for 2025-2055 and 2056-2086 under (RCM) RCP 4.5 and RCP 8.5 climate scenarios using SWAT hydrological model to simulate runoff. Future projection of temperature and precipitation produced an increase trend in both future periods of RCP's as compared to the base period. A change in climate variables (temperature and precipitation) has significant impacts on the magnitude of runoff. Generally, average seasonal and annual runoff projection showed an increasing trend. Average annual runoff may increases by $+24.5 \%$ and by $+23.6 \%$ at $2025-2055$ of RCP 4.5 and RCP 8.5 and by $+23.6 \%$ and by $+73.2 \%$ at $2056-2086$ of RCP 4.5 and RCP 8.5 respectively compared to base line period (1987-2017). These results indicated that the changes in temperature and precipitation due to climate change may result in positive impacts on runoff of Hangar watershed. However, there are many sources of uncertainty during downscaling of climate and simulation of hydrological models. Hence, the findings of this study could be accepted with care and be considered as indicator of the future expectation rather than accurate predictions. For this study, only two climate scenarios of RCM were used and the hydrological model didn't consider land use land cover changes of different periods during simulations. However, it is expected that changes in land use and land cover may interact with climate leading to different projections of future hydrological conditions. Therefore, future researches need to conduct on related topic should include land use and land cover changes explicitly.

\section{Conflict of interest}

Conflict of Interest- None

\section{References}

Abeygunawardena, P., Vyas, Y., Knill, P., Foy, T., Harrold, M., Steele, P., Tanner, T., Hirsch, D., Oosterman, M., Rooimans, J. and Debois, M., 2003. Poverty and Climate Change. Part 1. Reducing the Vulnerability of the Poor through Adaptation.

Chaemiso, S.E., Abebe, A. and Pingale, S.M., 2016. Assessment of the impact of climate change on surface hydrological processes using SWAT: a case study of Omo-Gibe river basin, Ethiopia. Modeling Earth Systems and Environment, 2(4), pp.1-15.

Chaulagain, N.P., 2009. Impacts of climate change on water resources of Nepal: The physical and socioeconomic dimensions. In IOP Conference Series: Earth and Environmental Science (Vol. 6, No. 29, p. 292029). IOP Publishing.

Chien, H., Yeh, P.J.F. and Knouft, J.H., 2013. Modeling the potential impacts of climate change on streamflow in agricultural watersheds of the Midwestern United States. Journal of Hydrology, 491, pp.73-88.

Conway, D., 1996. The impacts of climate variability and future climate change in the Nile Basin on water resources in Egypt. International Journal of Water Resources Development, 12(3), pp.277-296.

Deressa, T.T., Hassan, R.M., Ringler, C., Alemu, T. and Yesuf, M., 2009. Determinants of farmers' choice of adaptation methods to climate change in the Nile Basin of Ethiopia. Global environmental change, 19(2), pp.248-255.doi:10.1016/j.gloenvcha.2009.01.002.

Dile, Y.T., Berndtsson, R. and Setegn, S.G., 2013. Hydrological response to climate change for Gilgelabay River, in the Lake Tana basin-upper Blue Nile basin of Ethiopia. PloS one, 8(10).

Gebre, S.L., Tadele, K. and Mariam, B.G., 2015. Potential impacts of climate change on the hydrology and water resources availability of Didessa Catchment, Blue Nile River Basin, Ethiopia. J. Geol. Geosci, 4, p.193. 
Gleick, P.H., 1991. The vulnerability of runoff in the Nile Basin to climatic changes. Environmental Professional, 13(1), pp.66-73.

Hailemariam, K., 1999. Impact of climate change on the water resources of Awash River Basin, Ethiopia. Climate Research, 12(2-3), pp.91-96.

Huntington, T.G., 2006. Evidence for intensification of the global water cycle: review and synthesis. Journal of Hydrology, 319(1-4), pp.83-95.

IPCC, C.C., 2007. The physical science basis. Contribution of working group I to the fourth assessment report of the Intergovernmental Panel on Climate Change. Cambridge University Press, Cambridge, United Kingdom and New York, NY, USA, 996, p.2007.

Kim, J., Waliser, D.E., Mattmann, C.A., Goodale, C.E., Hart, A.F., Zimdars, P.A., Crichton, D.J., Jones, C., Nikulin, G., Hewitson, B. and Jack, C., 2014. Evaluation of the CORDEX-Africa multi-RCM hindcast: systematic model errors. Climate dynamics, 42(5), pp.1189-1202.

Kim, U., Kaluarachchi, J.J. and Smakhtin, V.U., 2008. Generation of Monthly Precipitation under Climate Change for the Upper Blue Nile River Basin, Ethiopia 1. JAWRA Journal of the American Water Resources Association, 44(5), pp.1231-1247.

Kingston, D.G. and Taylor, R.G., 2010. Sources of uncertainty in climate change impacts on river discharge and groundwater in a headwater catchment of the Upper Nile Basin, Uganda. Hydrology and Earth System Sciences, 14(7), pp.1297-1308.

Legesse, D., Vallet-Coulomb, C. and Gasse, F., 2003. Hydrological response of a catchment to climate and land use changes in Tropical Africa: case study South Central Ethiopia. Journal of hydrology, 275(1-2), pp.67-85.

Mehan, S., Kannan, N., Neupane, R.P., McDaniel, R. and Kumar, S., 2016. Climate change impacts on the hydrological processes of a small agricultural watershed. Climate, 4(4), p.56.

Musau, J., Sang, J., Gathenya, J. and Luedeling, E., 2015. Hydrological responses to climate change in Mt. Elgon watersheds. Journal of Hydrology: Regional Studies, 3, pp.233-246.

Setegn, S.G., Rayner, D., Melesse, A.M., Dargahi, B., Srinivasan, R. and Worman, A., 2011. Climate change impact on agricultural water resources variability in the Northern Highlands of Ethiopia. In Nile River Basin (pp. 241-265). Springer, Dordrecht.

Van Vuuren, D.P., Edmonds, J., Kainuma, M., Riahi, K., Thomson, A., Hibbard, K., Hurtt, G.C., Kram, T., Krey, V., Lamarque, J.F. and Masui, T., 2011. The representative concentration pathways: an overview. Climatic change, 109(1-2), p.5.

World Bank, 2006. Ethiopia: Managing water resources to maximize sustainable growth.

Xu, H., Taylor, R.G. and Xu, Y., 2011. Quantifying uncertainty in the impacts of climate change on river discharge in sub-catchments of the Yangtze and Yellow River Basins, China. Hydrology and Earth System Sciences, 15(1), p.333.

\section{Hosted file}

Figure 1.docx available at https://authorea.com/users/351805/articles/476289-evaluatingwatershed-hydrological-responses-to-climate-changes-at-hangar-watershed-ethiopia

\section{Hosted file}

Figure 2.docx available at https://authorea.com/users/351805/articles/476289-evaluatingwatershed-hydrological-responses-to-climate-changes-at-hangar-watershed-ethiopia

\section{Hosted file}


Figure 3.docx available at https://authorea.com/users/351805/articles/476289-evaluatingwatershed-hydrological-responses-to-climate-changes-at-hangar-watershed-ethiopia

\section{Hosted file}

Figure 4.docx available at https://authorea.com/users/351805/articles/476289-evaluatingwatershed-hydrological-responses-to-climate-changes-at-hangar-watershed-ethiopia

\section{Hosted file}

Figure 5.docx available at https://authorea.com/users/351805/articles/476289-evaluatingwatershed-hydrological-responses-to-climate-changes-at-hangar-watershed-ethiopia

\section{Hosted file}

Figure 6.docx available at https://authorea.com/users/351805/articles/476289-evaluatingwatershed-hydrological-responses-to-climate-changes-at-hangar-watershed-ethiopia

\section{Hosted file}

Figure 7.docx available at https://authorea.com/users/351805/articles/476289-evaluatingwatershed-hydrological-responses-to-climate-changes-at-hangar-watershed-ethiopia

\section{Hosted file}

Figure 8.docx available at https://authorea.com/users/351805/articles/476289-evaluatingwatershed-hydrological-responses-to-climate-changes-at-hangar-watershed-ethiopia

\section{Hosted file}

Figure 9.docx available at https://authorea.com/users/351805/articles/476289-evaluatingwatershed-hydrological-responses-to-climate-changes-at-hangar-watershed-ethiopia 